\title{
Biomechanical evaluation of microbial cellulose (Zoogloea sp.) and expanded polytetrafluoroethylene membranes as implants in repair of produced abdominal wall defects in rats ${ }^{1}$
}

\author{
Avaliação biomecânica de membranas de celulose microbiana (Zoogloea sp.) e de \\ politetrafluoretileno expandido como implantes no reparo de defeitos produzidos na \\ parede abdominal em ratos
}

\author{
Suyiene Cordeiro FalcãoI Antônio Roberto de Barros Coelho"I Joaquim Evêncio Neto ${ }^{\text {III }}$ \\ ${ }^{\text {I }}$ PhD, Veterinary Science - Department of Veterinary Medicine - Federal Rural University of Pernambuco, Brazil. \\ II PhD, Associated Professor- Department of Surgery- Federal University of Pernambuco, Brazil. \\ ${ }^{\text {III }} \mathrm{PhD}$, Associated Professor - Department of Animal Morphology and Physiology - Federal Rural University of Pernambuco, Brazil.
}

\begin{abstract}
Purpose: To evaluate the Load of Rupture of implants of membranes of microbial cellulose (Zoogloea sp.) and extended polytetrafuoroethylene in sharp defects of abdominal wall of rats. Methods: Sixty Wistar male rats, with a mean weight of $437,7 \mathrm{~g} \pm 40,9$, anesthetized by a mixture of ketamine $(5 \mathrm{mg} / 100 \mathrm{~g})$ and xylazine $(2 \mathrm{mg} / 100 \mathrm{~g})$, were submitted to a rectangular $(2 \times 3 \mathrm{~cm})$ excision of the abdominal wall, including fascia, muscle and peritoneum, and treated with membranes of microbial cellulose (MC) (MC Group- 30 animals) or extended polytetrafluoroethylene (ePTFE) (ePTFE Group- 30 animals). Each group was subdivided in $14^{\text {th }}$ POD, $28^{\text {th }}$ POD and $60^{\text {th }}$ POD Subgroups. Under anesthesia, animals were submitted to euthanasia at $14^{\text {th }}$ POD, $28^{\text {th }}$ POD and $60^{\text {th }}$ POD for evaluation of Load of Rupture. Results: Load of Rupture levels were significantly elevated $(\mathrm{p}<0,05)$ among $14^{\text {th }}, 28^{\text {th }}$ and $60^{\text {th }}$ postoperative days from each Group. When compared between groups, values of Load of Rupture were significantly larger $(p<0,05)$ in ePTFE Group than in MC Group. Conclusion: Resistance to strength at implant/host interface was more pronounced in PTFEe Group than in MC Group.
\end{abstract}

Key words: Membranes, Artificial. Zoogloea. Polytetrafluoroethylene. Implants, Experimental. Abdominal wall. Tensile Strength. Rats.

\section{RESUMO}

Objetivo: Avaliar a Carga de Ruptura de implantes de membranas de celulose microbiana (Zoogloea sp.) e de politetrafluoretileno expandido em defeitos agudos produzidos na parede abdominal de ratos. Métodos: Sessenta ratos machos Wistar, com média de peso de 437,7g $\pm 40,9$, anestesiados com uma mistura de cetamina ( $5 \mathrm{mg} / 100 \mathrm{~g})$ e xilazina (2mg/ $100 \mathrm{~g}$ ), foram submetidos à excisão retangular $(2 \times 3 \mathrm{~cm})$ na parede ventral do abdômen, incluindo fáscia, músculo e peritônio. Subseqüentemente, foram tratados com implante de membranas de celulose microbiana (CM) (Grupo CM - 30 animais) ou de politetrafluoretileno expandido (PTFEe) (Grupo PTFEe - 30 animais). Cada grupo foi ainda subdividido nos Subgrupos $14^{\circ} \mathrm{DPO}, 28^{\circ} \mathrm{DPO}$ e $60^{\circ} \mathrm{DPO}$. Os animais foram submetidos à eutanásia com doses letais de tiopental no $14^{\circ} \mathrm{DPO}, 28^{\circ} \mathrm{DPO}$ e $60^{\circ}$ DPO, para avaliação da Carga de Ruptura na área do implante. Resultados: Os níveis da Carga de Ruptura foram significativamente elevados ( $\mathrm{p}<0,05$ ) entre os Subgrupos $14^{\circ} \mathrm{DPO}, 28^{\circ} \mathrm{DPO}$ e $60^{\circ} \mathrm{DPO}$ de cada grupo estudado. Quando comparados entre Grupos, os valores da Carga de Ruptura foram significativamente maiores $(\mathrm{p}<0,05)$ no Grupo PTFEe do que no Grupo CM. Conclusão: A interface implante/hospedeiro apresentou maior resistência a tração no Grupo PTFEe do que no Grupo CM.

Descritores: Membranas artificiais. Zoogloea. Politetrafluoretileno. Implantes experimentais. Parede abdominal. Resistência à tração. Ratos.

1. Research performed at Laboratory of Experimental Surgery-Department of Surgery- Federal University of Pernambuco, Brazil. 


\section{Introduction}

The best method for the treatment of muscleaponeurotics defects of the abdominal wall is the approach, without tension, of fibromuscular structures of the own patient's tissue.

However, in some circumstances the repair can be affected by the great distance among the edges of the defect or by the lack of tissue with characteristics for an appropriate approach. In these cases, synthetic and biological prostheses, or even muscular grafts, vascularized or free, can be used for reconstruction ${ }^{1}$. The synthetic prostheses are of high cost and vascularized or free muscle grafts frequently constitute complex and prolonged surgeries that imply in creation of weak sites in surrounding areas of defect, that could need repair ${ }^{1,2}$.

Certain bacteria, algae and fungi produce cellulose ${ }^{3}$. In the last years, because of its good mechanical properties and biocompatibility, there was an increasing interest in bacterial cellulose, produced by the Acetobacter xylinum and its application in medicine. Important examples include products for temporary skin substitution and tissue replacement. These activities have been accompanied by the isolation of new bacterial strain producing biocellulose ${ }^{3}$.

In Northeast of Brazil, cellulose membrane was produced in the Estação de Cana-de-Açúcar de CarpinaUFRPE, by the microorganism Zoogloea sp. ${ }^{4}$.

Finally, it is not of our knowledge reports of previous use of cellulose membranes produced by the microorganism Zoogloea sp. or by other bacterial species, as repair of muscle-aponeurotics defects of the abdominal wall, in experimental or clinical scope.

Our purpose was to study comparatively the Load of Rupture of implants using membranes of bacterial cellulose and polytetrafluoroethylene in sharp defects of abdominal wall produced in the rat.

\section{Methods}

The microbial cellulose membrane is constituted by an exopolyssacharide produced by the bacteria Zoogloea sp., isolated by the Instituto de Antibióticos da Universidade Federal de Pernambuco, obtained in static culture, having molasses of the sugar-cane as culture medium. The non soluble content in water reaches $88 \%$ of the components of the gross membrane of exopolyssacharide ${ }^{4,5}$.

A double layer of this microbial cellulose (MC) was used. It was compressed and then evaporated on the air during the dehydration process, conserved in isopropyl alcohol moisturized at $20 \%$, conditioned in polypropylene envelopes and sterilized in $\gamma$ rays $^{\mathrm{a}}$. This process propitiates membranes with pores of mean diameter of $0,07 \mu \mathrm{m}(70 \mathrm{~nm})$ 5.

The film of expanded polytetrafuorethyene $(\mathrm{ePTFE})^{\mathrm{b}}$ was obtained from vascular prostheses of internal diameter of $8 \mathrm{~mm}$ and wall thickness of $0,8 \mathrm{~mm}$, with pores of
$25 \mu \mathrm{m}$, sectioned in longitudinal direction, after removal of the external helical structure. Rectangles of $2 \times 3 \mathrm{~cm}$ were prepared, conditioned in polypropylene envelopes and submitted to the sterilization in $\gamma$ rays.

Sixty male Wistar rats, with mean weight of $437,7 \mathrm{~g} \pm 40,9$, were conditioned in appropriate cages, fed with specific food ${ }^{\mathrm{c}}$ and mineral water ad libitum, before they were submitted to the procedures considered in the project.

The animals were distributed in two groups: A) Microbial Cellulose Group (MC Group): composed of 30 animals submitted to a sharp defect of the ventral wall of the abdomen, including fáscia, muscle and peritoneum, being treated with membrane of microbial cellulose; B)Expanded Polytetrafluorethylene Group ( ePTFE Group): composed of 30 animals submitted to the same procedure of MC Group , being treated with membrane of expanded polytetrafluorethylene;

Each group was subdivided in three subgroups of 10 rats, in agreement with the evaluation period, being denominated of $14^{\text {th }}$ POD, $28^{\text {th }}$ POD and $60^{\text {th }}$ POD Subgroups (Figure 1).

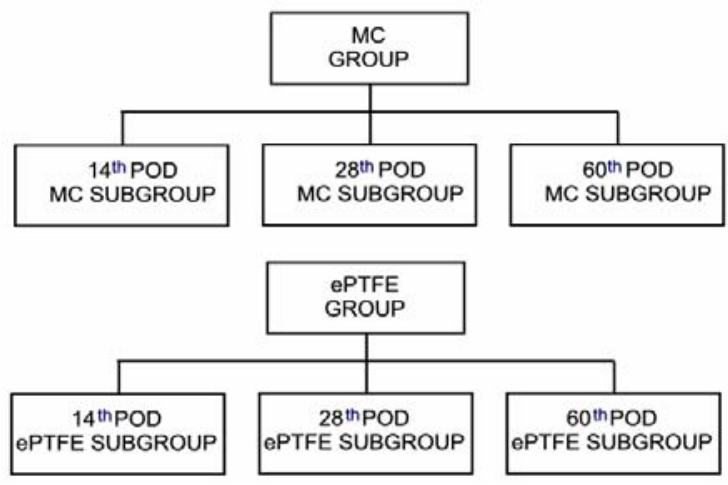

FIGURE 1 - Distribution of groups and subgroups

Anesthesia was accomplished with a mixture of cloridrate of ketamine $(5 \mathrm{mg} / 100 \mathrm{~g}$ of weight $)$ and cloridrate of xylazine $(2 \mathrm{mg} / 100 \mathrm{~g}$ of weight $)$, preceded by sulphate of atropine $(0,044 \mathrm{mg} / \mathrm{kg})^{\mathrm{d}}$, all administered by intramuscular route.

Under aseptic conditions, a middle incision of five $\mathrm{cm}$ was accomplished in the skin and subcutaneous layers of the abdominal ventral area of the animals. These plans were dissected from the aponeurotic layer of the corresponding area, followed by placement of superficial retractors, to allow the creation of an area for the production of muscle-apneurotic sharp defect .

Through a mold made of RX film, measuring $2 \mathrm{~cm}$ of width for $3 \mathrm{~cm}$ of length, the defect was produced, centered in the middle line of abdomen, $1 \mathrm{~cm}$ below the xifoid appendix. A full thickness wall involving fascia, musculature and peritoneum were excised. In the MC Group, membrane of microbial cellulose was sutured at the level of the muscleaponeurotic defect with polypropilene $4-0$ and continuous suture, anchored at the four angles of the rectangle. In the ePTFE Group the same surgical procedures adopted in the precedent group were accomplished (Figure 2). Then the skin was closed with thread of nylon ${ }^{\mathrm{f}} 4-0$ through an interrupted suture.

\footnotetext{
a Departamento de Energia Nuclear da UFPE

b GoreTex ${ }^{\circledR}$, W. L. Gore \& Associates, Inc. ,Newark, DE.

c Labina, Laboratório Nestle/Purina/PetCare Company, São Lourenço da Mata PE.

${ }^{d}$ Protocol for anesthesia in rodents adopted at the Núcleo de Cirurgia Experimental

e Prolene ${ }^{\circledR}$, Ethicon, Johnson \& Johnson Comércio e Distribuição Ltda.

${ }^{\mathrm{f}}$ Mononylon ${ }^{\circledR}$, Ethicon , Johnson \& Johnson Comércio e Distribuição Ltda.
} 


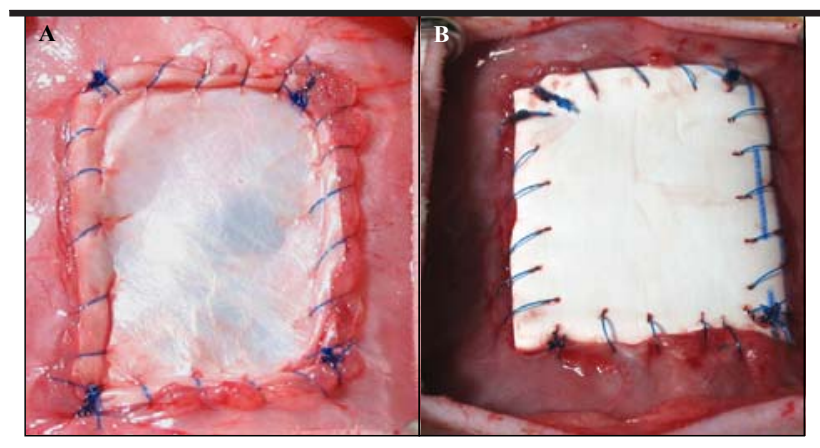

FIGURE 2 - Suture placed on microbial cellulose (A) and polytetrafluoroethylene (B) membranes

A device for the biomechanical measurement of

Load of Rupture at the implant/host interface was built in the Núcleo de Cirurgia Experimental (Figure 3).

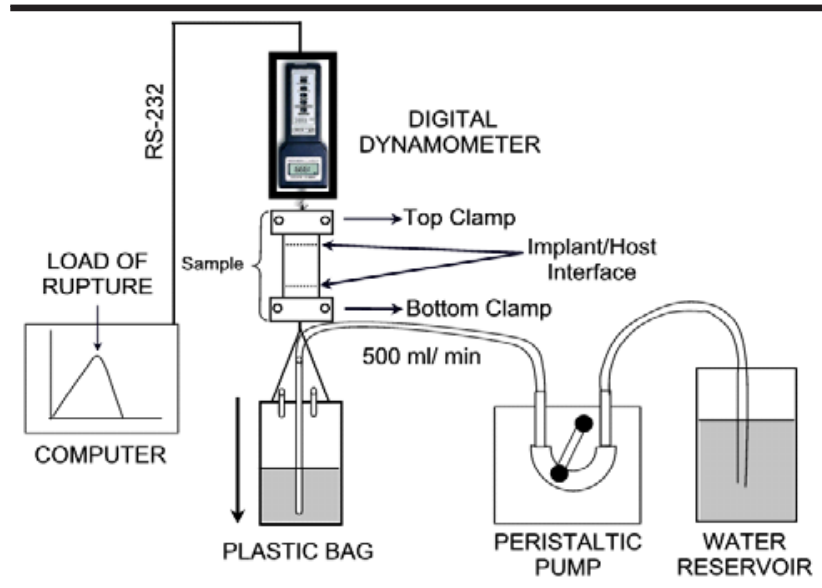

FIGURE 3 - Device for measurement of Load of Rupture

The applied load to the tissue sample was provided by a system of distilled water pumping, with a constant flow of $500 \mathrm{ml} / \mathrm{min}$, into a plastic bag, which weight exerts traction in the implant/host sample.

Sample was positioned in the top and bottom clamps and tightened (Figure 4).

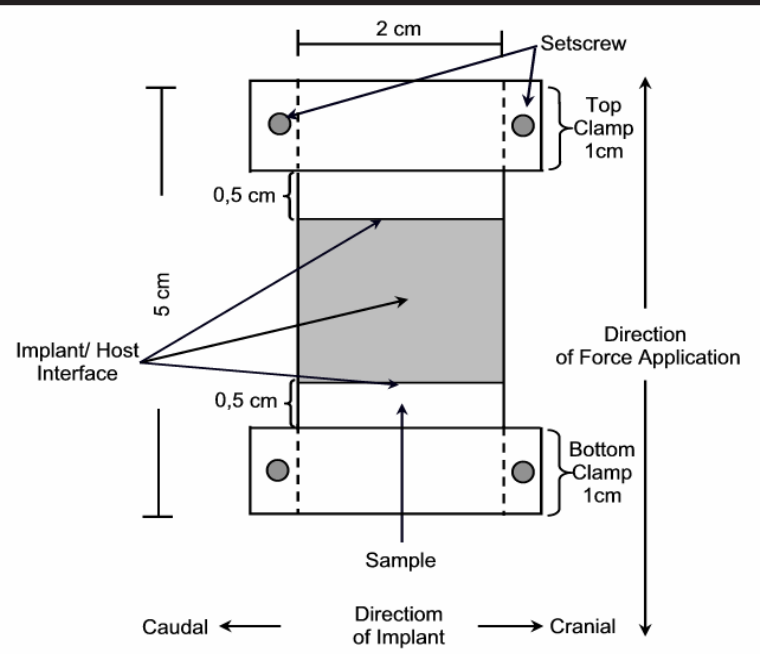

FIGURE 4-Sample positioned for biomechanical evaluation

Top clamp was attached to a Digital Dynamometer ${ }^{\circledR}$ and the bottom clamp was connected to the plastic bag. The plastic bag, moved down by an increment of constant weight, applied paralel to the sample. The dinamometer expressed the Load of Rupture in Kgf (scale precision: $\pm 0.5 \%$ ), (resolution: $0.01 \mathrm{~kg}$ ). A serial interface RS-232 was connected between the dynamometer and a computer and a dedicated software displays results as curves and tables.

Animals were submitted to euthanasia with lethal doses of thiopental $\AA^{\mathrm{h}}$ to obtain samples.

The sample was composed by implant and part of the abdominal musculature, free from suture, measuring $5 \times 2$ $\mathrm{cm}$, including the segment inserted within clamps $(1 \mathrm{~cm}$ in each end), so that the implant/tissue rectangle between clamps measured $3 \times 2 \mathrm{~cm}$ (Figure 4).

For validation of biomechanical test, only ruptures occurring in the implant/host interface were considered, not being computed results where the rupture occurs out of these structures, (i.e. abdominal musculature).

The test of differences of means (two tailed Student's " $t$ " test), with probability of error of $p<0,05$ were applied between the averages of obtained values of Load of Rupture (in Kgf):

A) in $14^{\text {th }}$ POD, $28^{\text {th }}$ POD and $60^{\text {th }}$ POD Subgroups of the Microbial Cellulose Group (Group MC);

B) in $14^{\text {th }}$ POD, $28^{\text {th }}$ POD and $60^{\text {th }}$ POD Subgroups of the Expanded Polytetrafluorethylene Group (ePTFE Group);

C) in $14^{\text {th }}$ POD, $28^{\text {th }}$ POD and $60^{\text {th }}$ POD Subgroups of each Group, in corresponding periods (Figure 5). Observations were made on the presence infiltration within the implants of microbial cellulose and expanded polytetrafluoroethilene.

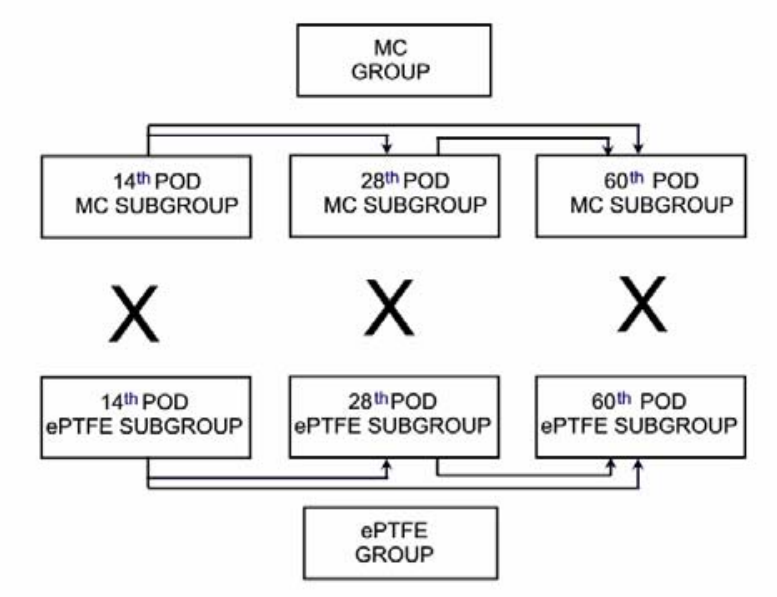

FIGURE 5 - Diagram showing statistical analysis programmed for Load of Rupture

\section{Results}

Comparative analysis accomplished among the averages of the values of the Load of Rupture obtained in the animals of $14^{\text {th }}$ POD, $28^{\text {th }}$ POD and $60^{\text {th }}$ POD Subgroups of MC Group are shown in graphic form (Figure 6).

${ }^{g}$ Lutron FG-20 kg- Rs232- Taiwan, Impac Instrumentos de Medição - BR

${ }^{\text {h}}$ Thiopentax, Laboratório Cristália-BR 


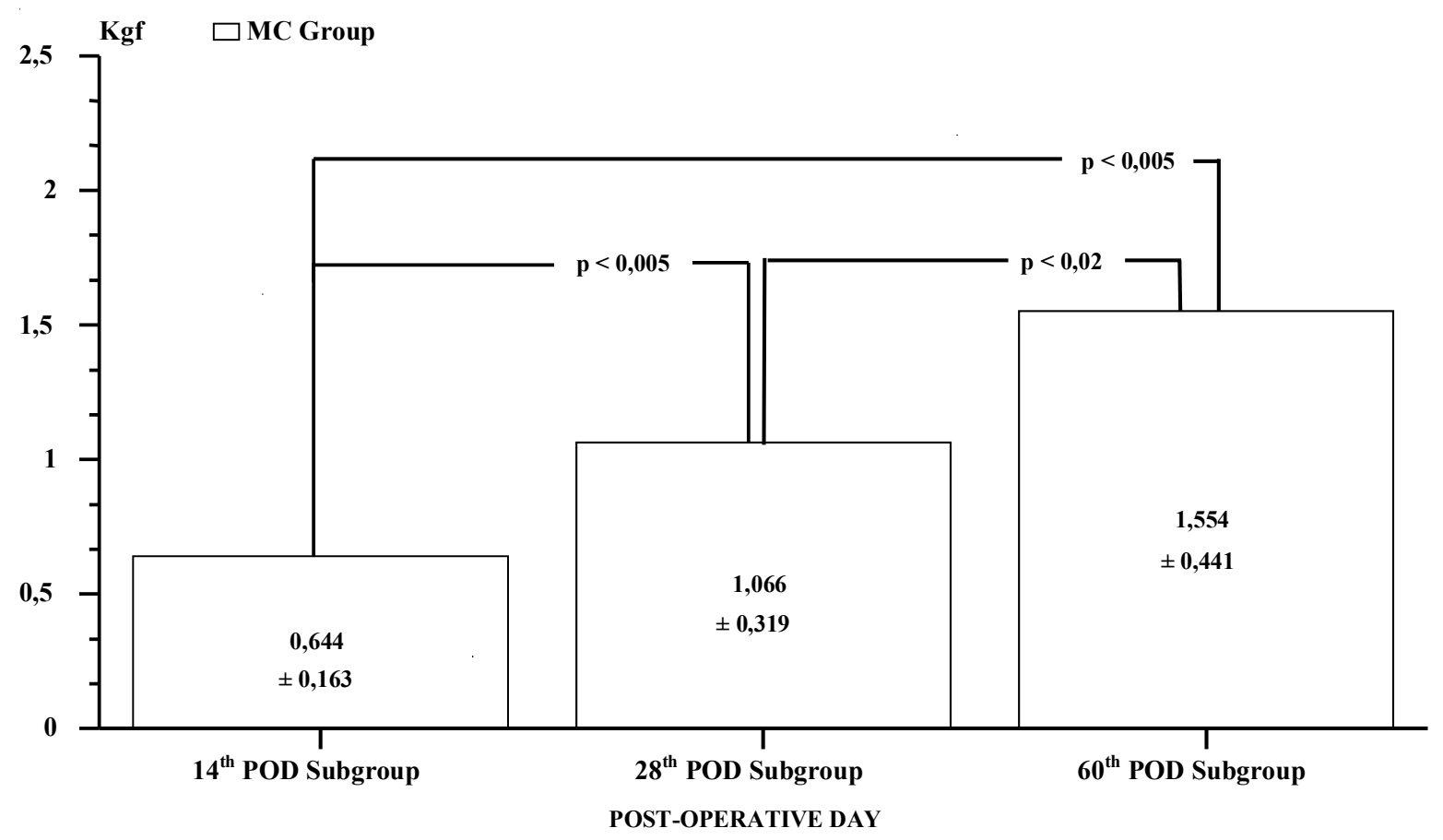

FIGURE 6 - Graph showing results of statistical analysis between mean values of Load of Rupture (Kgf) obtained in subgroups of MC group

Comparative analysis accomplished among the averages of the values of the Load of Rupture obtained in the animals of $14^{\text {th }}$ POD, $28^{\text {th }}$ POD and $60^{\text {th }}$ POD Subgroups of ePTFE Group are shown in graphic form (Figure 7).

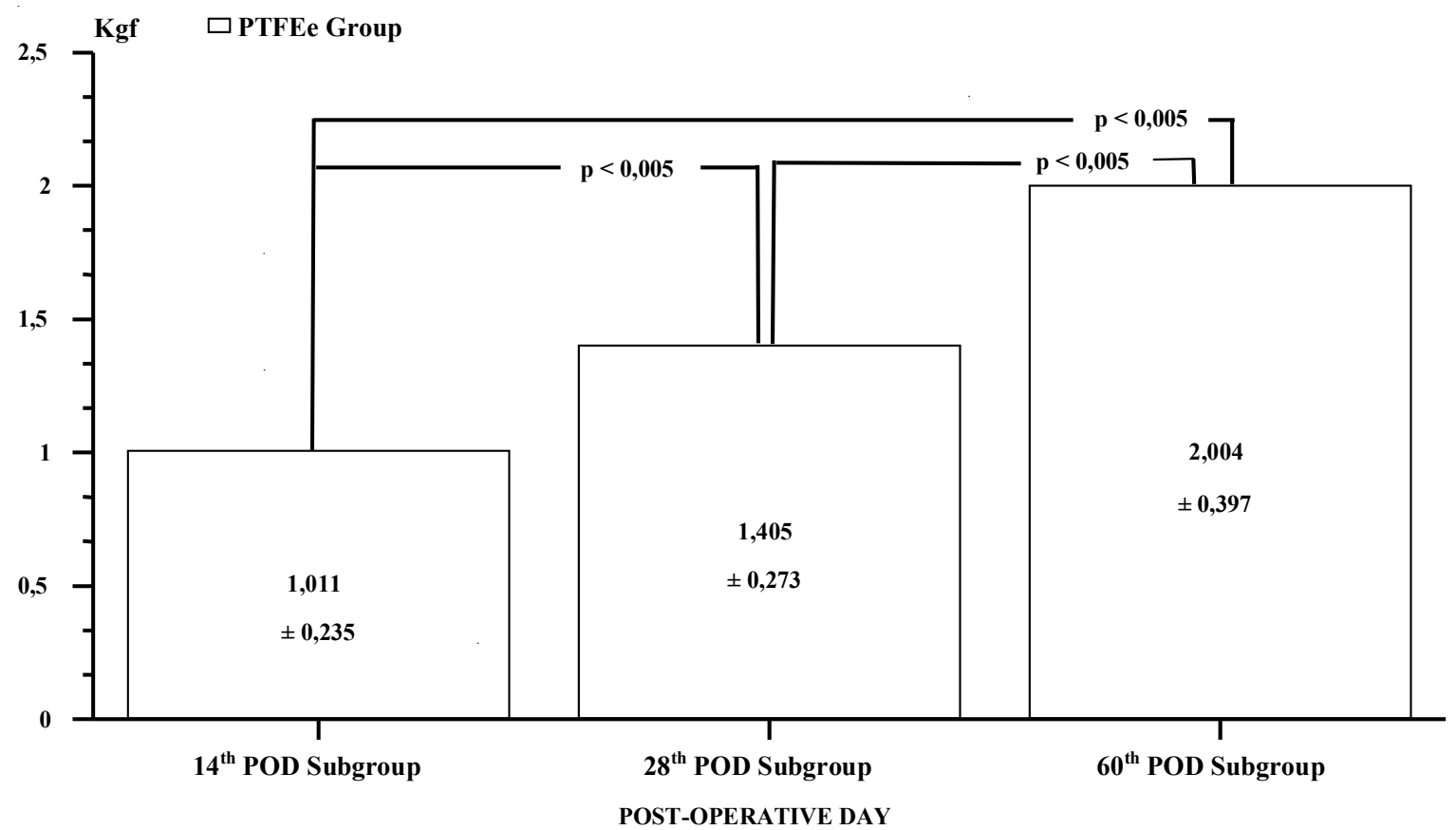

FIGURE 7 - Graph showing results of statistical analysis between mean values of Load of Rupture (Kgf) obtained in subgroups of ePTFE group

Comparative analysis accomplished between the averages of the values of the Load of Rupture obtained in the animals of $14^{\text {th }}$ POD, $28^{\text {th }}$ POD and $60^{\text {th }}$ POD Subgroups of MC Group and those obtained in the animals of $14^{\text {th }}$ POD, $28^{\text {th }}$ POD and $60^{\text {th }}$ POD Subgroups of ePTFE Group, in corresponding periods, are shown in graphic form (Figure $8)$. 


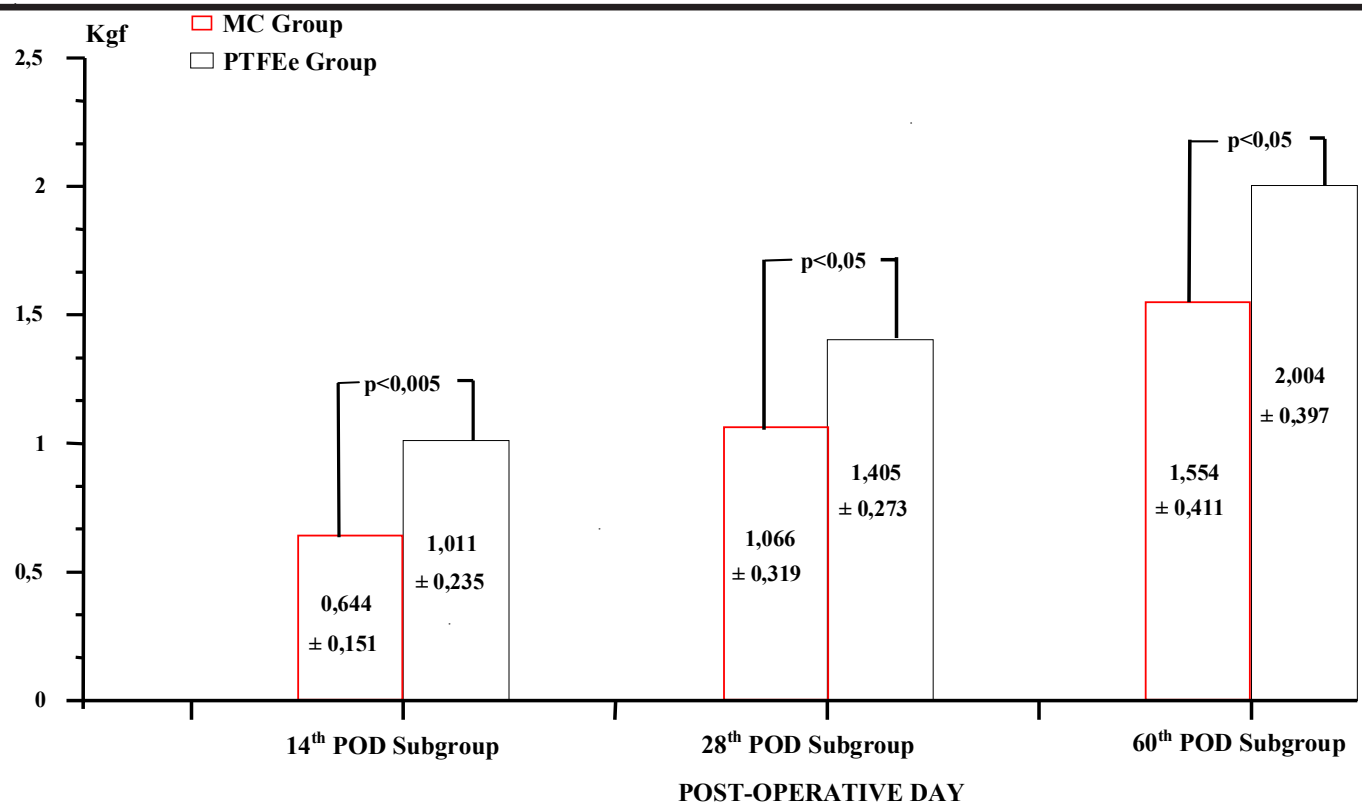

FIGURE 8 - Graph showing results results of statistical analysis between mean values of Load of Rupture (Kgf) obtained in MC Group compared to those obtained in ePTFE Group, in corresponding periods

Infiltration of host tissue within implants was observed only in ePTFE Group (Figures 9 and 10)

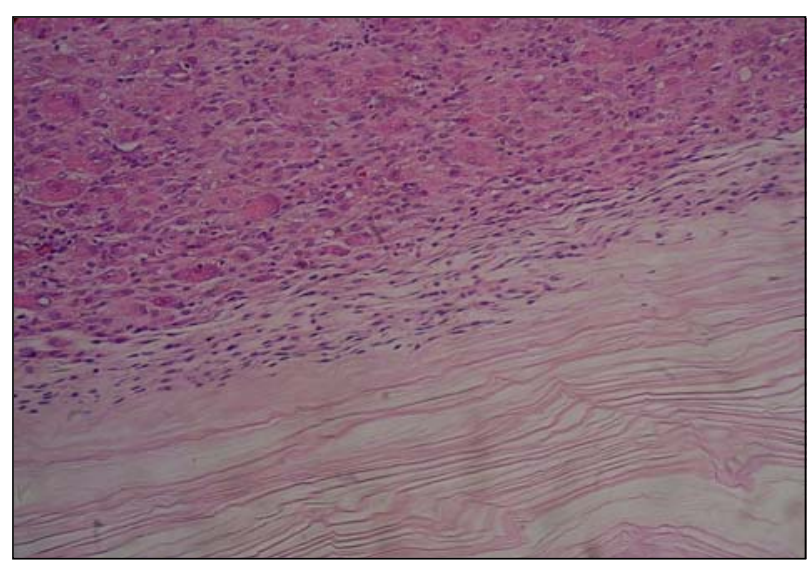

FIGURE 9 - Cellulose/host interface without infiltration of host tissue. Rat $n^{\circ} 38,60^{\text {th }}$ POD.

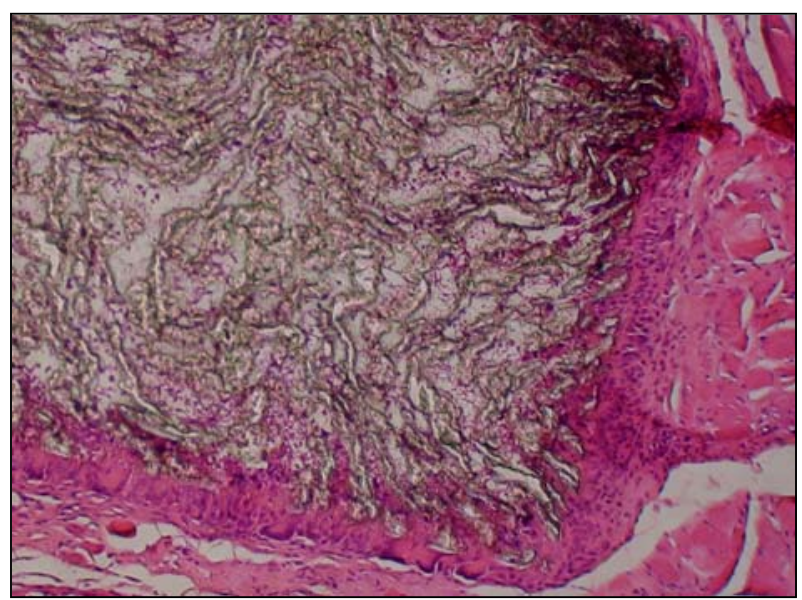

FIGURE 10 - ePTFE/host interface with infiltration of host tissue. Rat $n^{0} 24,60^{\text {th }}$ POD.

\section{Discussion}

The use of microbial cellulose (Acetobacter xilynum) has been suggested in different areas of medicine as: substitute of blood vessels and linfatics ${ }^{6,7}$; substitute of hollow internal organs as ureter, trachea and digestive tract ${ }^{6,7,8}$; cuff for reconstruction of nerves ${ }^{7}$; substitute of duramater ${ }^{9,10}$; substitute of the abdominal wall, skin, subcutaneous tissue, articulation, cartilage and reinforcement of areas of decreased resistance in the abdominal wall, esophagus and intestinal tube ${ }^{8}$; threads ${ }^{11}$; agent for increases soft tissue, reconstruction of the pelvic floor, suspension of bladder, repair of hernias and patch for inguinal hernias ${ }^{9}$.

In humans, microbial cellulose (Acetobacter xilynum) has been used on lesions of tegument (serious burns, skin graft ( in the donor and receiving areas), facial peeling, infectious dermolysis, abrasion of tattoos, chronic ulcers, Hanseníase of the distal members ${ }^{12,13}$. Experimental studies for clinical application have been accomplished with membrane produced by the Acetobacter xilynum in several conditions as: protective cover for reconstruction of nerves ${ }^{14}$; duraplasty ${ }^{15}$; healing of epithelial lesions of cornea $^{16}$; healing of duodenal lesions ${ }^{17}$; substitute of blood vessels ${ }^{18}$; cuffs for of reconstruction of micronerves ${ }^{18}$; reconstruction of the retroperitoneum ${ }^{19}$; and technical training in microsurgery ${ }^{18}$.

With the creation of a research group named biopolímero da cana de açúcar at the Federal University of Pernambuco, studies of biocompatibility of the microbial cellulose produced by Zoogloea $s p^{20,21,22,23}$. The satisfied results authorize the accomplishment of experimental research for clinical application. Thus, studies were performed on: repair of stomach and bladder lesions ${ }^{24,25}$; substitution and patch of blood vessels ${ }^{26}$; repair of tympanic lesions ${ }^{27}$; suburethral slings for treatment of urinary incontinence ${ }^{28}$; urethroplasty ${ }^{29}$; reconstruction of tunica 
albuginea of the pennis ${ }^{30}$; treatment of vesico-ureteral reflux ${ }^{31}$; and dressing after surgical correction of hypospadia ${ }^{32}$.

Experimentally, in Veterinary Medicine, the reports consulted about use of biocelulose produced by the Acetobacter xylinum refer to few applications for: conduit for isolation in reconstruction of peripheral nerves ${ }^{33}$; healing of experimental wounds of bovine mammary teats ${ }^{34}$; healing of experimental tegument wounds in equine ${ }^{35}$ and swine ${ }^{36}$; prophylaxis of the formation of membrane post laminectomy in $\operatorname{dogs}^{37}$ and healing of incisional experimental lesions of the cornea in $\operatorname{dog} \mathrm{s}^{38}$. Clinically, gross (brute) membrane of bacterial cellulose produced by the Zoogloea $s p$. was firstly used in healing of natural wounds of $\operatorname{dogs}^{39.40}$.

In this review, no reports (experimental or clinical) on the use of microbial cellulose membrane were found as repair of defects of the abdominal wall in humans or animals.

Increases of resistance in the subgroups of the MC Group (Figure 6) and ePTFE Group (Figure 7) along the time, may be related to the evolution of the healing process, predominantly inflammatory at the early phase and with prevalence of fibroblasts and collagen fibers in the remodeling process, allowing the biomaterial to be incorporating more firmly by the host, already mentioned in biocompatibility studies ${ }^{41,42}$.

Elevation of resistance in ePTFE Group as compared to MC Group, in corresponding periods (Figure 8) is indicative of better integration between polymeric synthetic material and host tissue.

The most important factor in the response to the implants by the host is the structure of the material, more specifically its porous structure. Materials that have reticular or macroporous structure, as polypropylene mesh, seem to produce better integration with organism of the receiver and better resistance to the traction in the zone of repair $^{43}$.

The microbial cellulose is characterized by a structure of microfibrils net. The cellulose membrane produced by the Zoogloea sp. presents small pores (empty spaces among the fibrils) with diameters around $0,07 \mu \mathrm{m}$ $(70 \mathrm{~nm})^{5}$. To have an idea of the size of these pores, it is enough to compare them with a thrombocyte (platelet), one of the smallest components of the blood, with a diameter of about $3 \mu \mathrm{m}^{18}$. The microporosity of the microbial cellulose doesn't allow ingrowth of host in cellulose structure (Figure 9).

The size of pores of the microbial exopolysacharide, resultant of the application of method of manual compression and exposition to the air for dehydration of the membrane, is reduced. Such pores, defined as spaces among the structural elements of the MC, enter in collapse due to superficial tension, as a consequence of liquid removal $^{44}$.

The expanded polytetrafluoroethylene (ePTFE) presents a microscopic structure composed of nodules interconnected each other by fibrils. The interior of the fibrils net is constituted by empty spaces with dimensions sufficiently large (up to $80 \mu \mathrm{m}$ ), to allow infiltration of tissue from host ${ }^{45}$. The porosity of ePTFE is an important characteristic in synthetic materials for implant that allows the infiltration of connective tissue into the material, propitiating better integration between the implant and the organism ${ }^{46}$. In the present work it was used implants of ePTFE with pore diameters of $25 \mu \mathrm{m}$, therefore, dimension enough to allow the penetration within implants with cellular elements and host tissue (Figure 10), starting from $14^{\text {th }}$ POD. Reports indicate that starting of this process can be observed from $7^{\text {th }} \mathrm{POP}^{42}$.

The multiperforated cellulose membrane, partially dehydrate membrane and the gel form (by ultrasonic fragmentation of the membrane) interposed between sheets of cellulose (sandwich) are being tested at Núcleo de Cirurgia Experimental associated with Laboratório de Canade-Açúcar da Universidade Federal Rural de Pernambuco, in the sense to obtain a product that allows better integration with host tissue.

\section{Conclusion}

In the experimentation conditions, and with a probability of error of $5 \%$, the implant/host interface presented larger resistance in ePTFE Group as compared with MC Group.

\section{References}

1- Santillán-Doherty P, Jasso-Victoria R, Sotres-Vega A, Olmos R, Arreda JJ, Garcia D, Gaxiola M. Reparacíon de defectos de pared tóracoabdominal de perros com bioprótesis de pericárdio bovino. Rev Invest Clin.1995;47(6):439-46.

2- Gutierrez-Sampério C, Vera-Garcia FJ, Figueroa Cárdenas JD, Gallegos-Corona MA. Bioprotesis de pericárdio bovino tratado com glutaraldehido ( PBTG ) en la reconstruccion de la pared abdominal. Cir Ciruj. 2002;70(4):257-66.

3- Klemm D, Heublein B, Fink HP, Bohn A. Cellulose: Fascinating biopolymer and sustainable raw material. Angew Chem Int Ed. 2005;44:3358 - 93.

4 Paterson-Beedle M, Kennedy JF, Melo FAD, Lloyd LL, Medeiros. A cellulosic exopolysaccharide produced from sugarcane molasses by a Zoogloea sp. Carbohydr Pol. 2000;42(4):375—83.

5- Melo FAD. Contribuição ao estudo cinético da produção de polissacarídeo extracelular por Zoogloea sp em melaço de cana-de-açúcar [Tese de Doutorado]. Universidade Federal de Pernambuco: Centro de Tecnologia e Geociências; 2003.

6- Yamanaka S, Ono E, Watanabe K, Kusakabe M, Suzuki Y, inventors; Ajinomoto Co., Inc. Sony Corporation, assignee. Hollow microbial cellulose, process for preparation thereof, and artificial blood vessel formed of said cellulose. European patent, EP0396344A2, 1990 Nov. 07. Available from: http: //www. delphion.com. 
7- Klemm D, Udhardt U, Marsch S, Shumann J, inventor. Method and device for producing shaped microbial cellulose for use as a biomaterial, especially for microsurgery. United State patent US2003/0013163, 2003 16 Jan. Available from: http: //www. delphion. com.

8- Ono E, Watabe O, Yamanaka S, inventors; Ajinomoto Co. Inc., assignee. Substitution material for living body texture. Japanese patent JP03165774A2, 198927 Nov. Available from: http: / /www. delphion.com.

9- Oster GA, Lentz Y, Koehler K, Hoon R, Serafica G, Mormino R, inventor; Xylus Corporation, assignee. Solvent dehydrated microbially-derived cellulose for in vivo implantation. United State Patent US6599518, 200329 Jul. Available from: http: // www.delphion.com.

10- Damien C, Heather AB, Oster GA Wright ES, Serafica G, inventor; Xylos Corportion, assignee. Dura substitute and a process for producing the same. United State patent US20050042263A1, 2005 24 Feb. Available from: http:// www. delphion. com.

11- Roberts EM, Hardison LK, Brown RM, inventor; Board o Regents the University of Texas, assignee. Production of microbial cellulose. European Patent, EP0186495B1, 19912 Oct. Available from: http:// www.delphion.com.

12- Fontana JD, Souza AM, Fontana CK, Torriani IL, Moreschi JC, Galloti B J et al. Acetobacter cellulose pellicle as a temporary skin substitute. Appl Biochem Biotechnol.1990;24/25:253-64.

13- Fontana JD, Franco VC, Souza SJ, Lyra IN, Souza AM. Nature of plant stimulator in the production of Acetobacter xylinum ("Tea Fungus") biofilm used in therapy. Appl Biochem Biotechnol. 1991;28/29:341-51.

14 Mello LR, Feltrin Y, Selbach R, Macedo Jr.G, Spautz C, Haas LJ. Uso da celulose liofilizada em lesões de nervos periféricos com perda de substância. Arq Neuropsiquiatr. 2001;59(2):372-9.

15- Mello LR, Feltrin LT, Fontes Neto PT, Ferraz FAP. Duraplasty with biosyntetic cellulose: an experimental study. J Neurosurg. 1997;86(1):14350.

16- Brik D. Aplicação de película de celulose em lesões epiteliais da córnea: estudo experimental comparativo. Rev Bras Oftalmol. 1991;50(4):21520.

17- Araújo CFR, Souza Filho ZA, Oliva LV, Greca FH, Santoro M, Baptista $C$ et al. Influência da película celulósica na cicatrização de lesões duodenais: estudo experimental. In: II Congresso Nacional de Cirurgia Experimental. n. 1, 1991, São Paulo. Anais do II Congresso Nacional de Cirurgia Experimental. São Paulo. Acta Cir Bras. 1991;(Supl. 1):52.

18- Klemm D, Schumamm D, Udhardt U, Marsch S. Bacterial synthetized cellulose: artifitial blood vessels for microsurgery. Prog Polym Sci. 2001;26(9):1561-603.

19- Ewald E, Malafaia O, Matias JEF, Campos ACL, Ribas-Filho JM, Mello LRO et al. Celulose liofilizada para fechamento de retroperitônio em ratos. Arq Bras Cir Dig. 2001;14(3):129-32.

20- Andrade CEMC, Aguiar JLA. Biopolímero da canade-açúcar: estudo de biocompatibilidade. In: X Congresso de Iniciação Científica (CONIC/ CNPQ/
UFPE), v II, 2002. Recife. Anais do X Congresso de Iniciação Científica (CONIC/CNPQ/UFPE), Editora Universitária, 2002, v. II, p. 191.

21- Castro CMMB, Aguiar JLA, Melo FAD, Silva WTF, Marques E, Silva DB. Citotoxidade de biopolímero de cana-de-açúcar. An Fac Med Univ Fed Pernamb. 2004;49(2):119-23.

22- Lima FR, Aguiar JL. A Biocompatibilidade comparada de gel de exopolisacarídeo de melaço cana-de-açúcar e de gel de polimetilacrilato com gordura autóloga. In: XIII Congresso de Iniciação Científica (CINIC/CNPQ/UFPE), outubro de 2005. Recife. Anais do XIII Congresso de Iniciação Científica(CONIC/CNPQ/UFPE), Recife. 2005. [CDROM].

23- Lima FR, Lima JRA, Hirakava P, Medeiros Jr.MD, Lima FMT, Aguiar JLA. Resposta inflamatória a biomembranas de polímero de cana-de-açúcar e telas de polipropileno ${ }^{\circledR}$ implantadas no peritônio parietal de ratos. An Fac Med Univ Fed Pernamb. 2005;50(1):37-9.

24- Ribeiro LM, Câmara Neto RD. Biomaterial extraído do melaço da cana-de-açúcar por ação microbiana, aplicado em lesões agudas no estômago de cães. Estudo da sobrevida e achados de necropsia. In: $\mathrm{X}$ Congresso de Iniciação Científica (CINIC/CNPQ/ UFPE), outubro de 2002. Recife. Anais do X Congresso de Iniciação Científica (CONIC/CNPQ/ UFPE), Recife. 2002. [CD-ROM].

25- Santos HFF, Câmara Neto RD. Aplicação de biopolímero extraído por ação bacteriana no melaço da cana-de-açúcar como "patch" em bexiga de cães. Nota prévia. In: X Congresso de Iniciação Científica (CONIC/CNPQ/UFPE), outubro de 2002. Recife. Anais do X Congresso de Iniciação Científica (CONIC/CNPQ/UFPE), Recife. 2002. [CD-ROM].

26- Marques SRB. Um novo substituto vascular: estudo experimental com biopolímero da cana-deaçúcar [Tese Professor Titular]. Universidade Federal de Pernambuco: Centro de Ciências da Saúde; 2006.

27- Silva DB, Aguiar JLA, Marques A, Coelho ARB, Rolin Filho EL. Miringoplastia com enxerto livre de membrana de polímero da cana-de-açúcar e fáscia autóloga em Chinchilla laniger. An Fac Med Univ Fed Pernamb. 2006;51(1):45-51.

28- Gonçalves R, Rangel A, Duarte JA, Andrade R, Vilar FO, Aguiar JL et al. Bio-Sling no tratamento da incontinência urinária de esforço: estudo experimental e primeiros ensaios clínicos. In: XXVIII Congreso de la Confederación Americana de Urologia-CAU,Recife, Jun. $17^{\text {th }}-22^{\text {th }}, 2006$. Int Braz J Urol. 2006;32(Suppl. 2):41.

29- Chagas HM, Aguiar JL, Montoro M, Vilar F, Pires JA, Pereira LA et al. Uretroplastia com biopolímero da cana-de-açúcar em cão. In: XXVIII Congreso de la Confederación Americana de UrologiaCAU,Recife, Jun. $17^{\text {th }}-22^{\text {th }}, 2006$. Int Braz J Urol. 2006;32(Suppl. 2):65.

30- Vilar F, Aguiar JL, Vilar S, Machado M, Pontes F, Lima R et al. Doença de Peyronie: estudo de um novo material com perspectiva de aplicação clínica. In: XXVIII Congreso de la Confederación Americana de Urologia-CAU,Recife, Jun. $17^{\text {th }}-22^{\text {th }}$ ,2006. Int Braz J Urol. 2006;32(Suppl. 2):167. 
31- Rangel AEO, Aguiar JLA, Lima SVC, Araújo FC, Vilar FO, Pires JAC et al. A new biomaterial for the treatment of vesicouretral reflux: experimental study In: XXVIII Congreso de la Confederación Americana de Urologia-CAU,Recife, Jun. $17^{\text {th }}-22^{\text {th }}$ ,2006. Int Braz J Urol. 2006;32(Suppl. 2):184.

32- Lima S, Aguiar J, Pereira LA, Machado M, Andrade $\mathrm{R}$, Lima $\mathrm{R}$ et al. A new dressing for hypospadias surgery.In: XXVIII Congreso de la Confederación Americana de Urologia-CAU,Recife, Jun. $17^{\text {th }}-22^{\text {th }}$ ,2006. Int Braz J Urol. 2006;32(Suppl. 2):189.

33- Torres MFP, Graça DL, Farias ELP. Reparação microcirúrgica de nervo periférico por meio de sutura, cola de fibrina ou bainha de BioFill® em ratos Wistar. Arq Bras Med Vet Zootec. 2003;55 (5):557-61

34 Marques JA, Moraes JRE, Teixeira Neto FJ. Tratamento alternativo de feridas de papilas mamárias de vacas através do emprego de membrana biológica (Biofill Produtos Biotecnológicos, Curitiba,PR). Braz J Vet Res Anim Sci. 1996;33(2):102-6.

35- Vaz BBD, Marques JA, Moraes JRE. Avaliação microscópica da evolução cicatricial de feridas cutâneas induzidas experimentalmente na espécie eqüina (Equus caballus), tratadas ou não com película de celulose. Ars Vet. 1997;13(1):17-27.

36- Wouk AFPF, Diniz JM, Círio SM, Santos H, Baltazar E L, Acco A. Membrana biológica (Biofill $®)$. Estudo comparativo com outros agentes promotores da cicatrização da pele em suínos: aspectos clínicos, histopatológicos e morfométricos. Arch Vet Scienc. 1998;3(1):31-7.

37- Costa RC, Pippi NL, Graça DL, Fialho SA, Alves A, Groff AC et al. The effects of free fat graft or cellulose membrane implants on laminectomy membrane formation in dogs. Vet J. 2006; 171(3):491-9.

38- Schoenau LSF, Pippi NL, Schossier JEV. Avaliação clínica preliminar do fechamento comparativo de incisões corneanas com sutura e Biofill (Película Celulósica). Ciênc Rural. 1993;23(2):173-7.
39- Coelho MCOC, Carrazoni PG, Monteiro VLC, Melo FAD, Mota RA, Tenório Filho F. Biopolímero produzido a partir da cana-de-açúcar para cicatrização cutânea. Acta Cir Bras. 2002;17 (supl. 1):11-3.

40- Melo FAD, Coelho MCOC, Ferreira VM, Monteiro VL, Carrazone PG. Biopolímero produzido a partir da cana de açúcar para cicatrização cutânea. In: VII CONGRESSO STAB. 1999, Londrina. Anais do VII Congresso STAB. Londrina, p. 251-255.

41- Andrade CEMC, Aguiar JLA. Biopolímero da canade-açúcar: estudo de biocompatibilidade. In: X Congresso de Iniciação Científica (CINIC/CNPQ/ UFPE), v II, 2002. Recife. Anais do X Congresso de Iniciação Científica (CONIC/CNPQ/UFPE), Editora Universitária, 2002, v. II, p. 191.

42- Kafejian-Haddad AP, Haddad-Filho D, GuidugliNeto J, Goldenbeg S. Estudo comparativo das reações teciduais de silicone e politetrafluoroetileno expandido no dorso de ratos. Acta Cir Bras. 1997; 12 (3):182-8.

43- Bellón JM, Contreras LA, Buján J, CarreraSanMartin A Experimental assay of Dual Mesh ${ }^{\circledR}$ polytetrafluoroethylene prosthesis (non-porous on one side) in the repair of abdominal wall defects. Biomaterials. 1996;17(24):2367-72.

44 Blaney CA, Brostin J, MacIntire TM, Minerath III $\mathrm{B}$, inventor; Kimberly- Clark Corporation, assignee. Absorbent structure comprising a microbial polysaccharide and a process of making the same. United State patent US5580348, 19963 Dez. Available: http://www.freepatentsonline.

45- Goldfarb D, inventor. Prosthetic vascular graft. US6436135, 20 Aug 2002. Available from: http:// www.freepatentsonline.com.

46- Balen EM, Diez-Caballero A, Hernandez-Lizoain JL, Pardo F, Torramade JR, Regueira FM et al. Repair of ventral hernias with expanded polytetrafluoroethylene patch. Br J Surg. 1998;85(10):1415-8.

\section{Correspondence:}

Antônio Roberto of Barros Coelho

Rua Galvão Raposo, 234

50610-330 Recife-PE Brazil

Phone/Fax: (55 81)3227-0142

arcoelho@globo.com
Conflict of interest: none Financial source: none

Received: August 29, 2007

Review: November 12, 2007 Accepted: December 18, 2007

\section{How to cite this article}

Falcão SC, Coelho ARB, Evêncio Neto J. Biomechanical evaluation of microbial cellulose (Zoogloea sp.) and expanded polytetrafluoroethylene membranes as implants in repair of produced abdominal wall defects in rats. Acta Cir Bras. [serial on the Internet] 2008 Mar-Apr;23(2). Available from URL: http://www.scielo.br/acb 